\title{
Culture Influence over Words and Phrases
}

\author{
Xiao Geng \\ Qingdao University of Science and Technology, Qingdao, China \\ Email: gxdonna@126.com
}

\begin{abstract}
Every language is a part of culture, it can not but serve and reflect culture needs, and culture also exerts a strong influence on language. We should not only focus on the distinction between foreign language and our mother tongue, we should also pay attention to the numerous features shared by the two languages. The paper discusses culture difference over words and phrases. Culture plays an important part in the translation of words and phases.
\end{abstract}

Index Terms — no equivalent, literal translation, globalization

\section{CRITERIA IN TRANSLATION}

The translation of words and phrases is more difficult to be mastered than the article translation. Sometimes even a word or a phrase takes much time to establish in translation. Translation should obey the translation criteria: faithfulness, smoothness, expressiveness and elegance. But sometimes we can't translate words and phrases just according to the above standards. Culture factor is an important part we should consider.

\section{Culture in Practice}

\section{A. History Influence in Practice}

For example, the word "ancient" has different meanings in different culture. Both China and Europe have the word. But in China we mean Qin and Han dynasties while in Europe they usually mean ancient Greece and Roman Times. As a translator, we should know the difference. China and Europe have different histories. "Ancient" means different periods of time in history. So when "ancient" is translated into Chinese, ancient Greece and Roman Times should be mentioned. And when "ancient" is translated into English, Qin and Han dynasties should be explained, so that the reader can have the exact understanding.

\section{B. Differences in Definition}

\section{Station and Stop}

We often hear some bus tell the passengers where to get off in English. For example, they say "The next station-Liao Yang Dong Lu". This sentence makes us uncomfortable because it is neither English nor translation. This is not English at all, not to say translation. The "station" is not properly used here. In Oxford Advanced Learner's Dictionary "station" means a) place where trains stop on a railway line b) similar place where buses and coaches stop. "Stop" means a place where a bus, train, etc, stops regularly (e. g. to allow passengers to get off or on). In Chinese we can make some mistakes to translate "station" and "stop". But from the definitions, we can see the differences. Many Chinese neglect his point and take it for granted that they have: the same Chinese meaning and they are equivalent. The translator makes such a mistake because he does not understand the different cultures. "Liao Yang Dong Lu" is regarded as "Chinese English". So, to the passengers, most of them are Chinese, it is of no use translating. And to the foreigners who can understand the next stop in Chinese, it is also of no use for this translation. "The next station -liao yang dong lu "should be translated into "The next stop--Liao Yang East Road", which can be regarded as English by foreigner.

2. Different meanings of "peasant" and "farmer"

Nowadays, we often translate "farmer" into "peasant". In fact, "peasant" in modern English has a strong derogatory sense of humor. In dictionary meaning, the meaning of "peasant" is :a) one of chiefly European class that tills the soil as small free landowners or hired labors b)a rascally person c) a rather uneducated ,uncouth person in the low income group .now people in the English speaking countries call people who work for agriculture farmers or farmer works. Farmer is a person who cultivates lands or crops or raises livestock. Farmer is a proper name for our Chinese "farmer", though "peasant" has been used for a long time by a number of Chinese people. A translator should not only translate the works but also impact the thought of people through translation and change their wrong ideas formed years ago.

\section{No Equivalent between English Original Words and Chinese}

"Faithfulness" is the most important criterion for translation. Faithfulness also includes the keeping of the original work in. But because of different cultures, English original works and Chinese translation cannot always be equivalent to. In this case, we should avoid word-for-word translation. For example,

"Did you say ' pig' or ' fig'?" said Mary.

"I said ' pig'." replied Alice .How to translate "pig" and "fig"? If we translate them respectively and we will make the 
readers perplexed. "pig" has no connection with "fig". So when we translate "fig", we can use a Chinese character "fig", which has the same rhyming word with "pig". This keeps the flavor of the original work and there is no need to explain.

English and Chinese are the individual and distinct system of two entirely different languages. English and Chinese are two entirely different languages. Each has an individual and distinct system. There are lots of dissimilarities between them. Because of this, we have to be familiar with both the language and the different cultures.

\section{Over-literal Translation}

\section{1. "breakfast" and "white hands"}

There are many words and phrases which we cannot translate over-literally. We must consider the culture factor. For example, there are two ways of translating the English word "breakfast". One is "the first meal of the day" which is an interpretation of word in terms of its actual referent. And the over-literal way of translating it will result in "meal which breaks a period of fasting". Though this looks much more faithful to the original meanings, it is surely misleading. It's terrible to translate the phrase "white hands" into Chinese if we use word-for-word translation. It means "start from scratch" or "build up from nothing". But in English ' white hands" means "pure", "unsullied, and "unstained. When we say "He has white hands", we cannot understand this sentence "His hand is white". In English it means "He is unstained".

2. The translation of "rest room"

Take "rest room" for another example. We translate the word "restroom" into "and so many people take it for granted that "rest-room" is a room to have a rest. But in English "rest-room" is a lavatory in a public building. Suppose a foreign teacher went into a teacher's rest-room to get relieved. How disappointed and embarrassed he will be when he finds there is no toilet.

3. Misunderstanding of "Wine" and "spirits"

Our Chinese people like to translate "white Wine" incorrectly. In China "white wine" is distilled out of water. The ethyl alcohol degree is usually above 50. But in English white wine is brewed out of grapes. The ethyl alcohol degree is only about 15 . "Spirits" or "liquor" should be used to the liquid distilled and "wine" is a general name for the liquid brewed out of grapes.

\section{E. Customs}

1. There are some words and phrases and customs in China, of which foreigners know nothing or they have quite different understanding. So when we translate this kind of words and phrases, we should be carefully. We translate "Moon Rabbit" instead of "jade Rabbit", because in Chinese myth the rabbit lived in the moon to accompany change. It has become another name for the moon. The ' Moon Rabbit" reflects the flavor of our old culture. If the readers know the old story, they will not misunderstand the translation and will not think the rabbit is made of jade.

In translation, the understanding to the original work is not in merely the understanding to the language. Language is a component of culture and is influenced and restrained by culture. We can translate "My God" into "sky". But if we translate "sky" into "God", it is not proper. In Chinese we do not have the definition of "God". If we translate it like that, the European and American readers with think Chinese people are familiar with Christ.

2. Necessarily explanation in translation of "dragon"

Different cultures make it necessary for the translator lo make some explanation after translation. For example, there are two ways to translate wishes their son to be dragon. One is "long to see one's son to succeed in life." another is "long to see one's son to become a dragon" (i.e. win success in the world). The first is liberal translation and the second is literal translation with explanation. The explanation is necessary because dragon has different meanings in English and Chinese paper. In the bible oath, dragon is the symbol of evil. It is formidable for Englishman and American Federation of Labor. But for our Chinese dragon is the symbol of emperor.

\section{F. Disparity between Cultures}

There are more other translation of words and phrases influenced by culture. We use "yellow video" while the American use "blue video". We use"red- eyes sick"while they use "green-eyed monster". No translation can exist without culture. No translation can be separated from culture. Even though we say "expose in the sun" in Chinese, no one of us will admit that we think that it is people who bathe the sun rather than the sun bathing people. The translation is affected by the way of thinking in the culture of different languages. There seems to exist some disparities between what people actually think and what is conveyed in the over-literal translation.

\section{GLOBALIZATION AND RECOGNITION OF SOME TRANSLATION}

\section{A. Loanwords and Globalization}

In the recent ten years, the contact between China and other counties become more and more frequent. More and more translation works appear in many fields, such as in economy, politics, trade and tourism. Culture communication is becoming more and more frequent. Different culture phenomenon is familiar to different people .there some words and phrases being accepted by other cultures and popular in other cultures. Cases in points are qigong, wushu, etc. these words have been accepted by English speaking country. Some words like "CD",,VCD","OK" and "E-mail" are used 
directly instead of being translated into Chinese.

\section{B. Recognition of Some Translation like "Telephone"}

In 1930s, people did not know how to translate "telephone", "laser" and so on into Chinese correctly. As years passed, people know more about these things and change their names into right words. The translator is intelligent to combine the euphony with the mellowness of the wine and hospitality of welcoming the guest. All these examples show the culture influence upon the translation of words and phrases.

\section{CONCLUSION}

"Leaning a language is a kind of learning the culture and the habit of the country where the language is spoken." Translation without knowing the culture is like shooting without taking aim. Before translation, we should learn the different cultures, including its tradition, habits, social customs, morals and so on. Culture exerts a strong influence on language. In the translation of words and phrases, culture background is essential. A translator without understanding the culture cannot translate well. We should take the culture factor as an important part in translation and translate words and phrases according to the rules of translation so as to get rid of unreasonable translation.

\section{REFERENCES}

[1] Basil Hatim. (2001). Communication across Cultures- Translation Theory and Contrastive Text Linguistics. Shanghai: Shanghai foreign Language Education Press.

[2] Coady, J.\&T. Huckin. (1997).Second Language Vocabulary Acquisition. Cambridge University Press.

[3] George Steiner. (2001).Aspects of Languages and Translation. Shanghai: Shanghai foreign Language Education Press.

[4] Jeremy Munday. (2001). Introducing Translation Studies-Theories and Application. London: Taylor \& Francis Group.

[5] Larry A. Samovar, Richard E. Porter \& Lisa A. Stefani. (2000). Communication Between Cultures. Foreign Language Teaching and Research Press.

[6] Lado, R. (1957).Linguistics Across Cultures. University Michigan Press.

[7] Liu, N. \& I.S.P. Nation. (1985). Factors Affecting Guessing Vocabulary in Context. RELC Journal 16(1) 32-33.

Xiao Geng was born in Weihai, China in 1970. She received her M.A. degree in linguistics from Qufu Normal University, China in 2004.

She is currently an associate professor in the School of Foreign Languages, Qingdao University of science and Technology, Qingdao, China. Her research interests include teaching methods and the Second Language Acquisition.

Prof. Geng is a member of the Institute of Linguistic Study. 